\title{
Aortic dilatation and miscarriages as a main presentation of FLNA mutation in a Croatian family: a case report
}

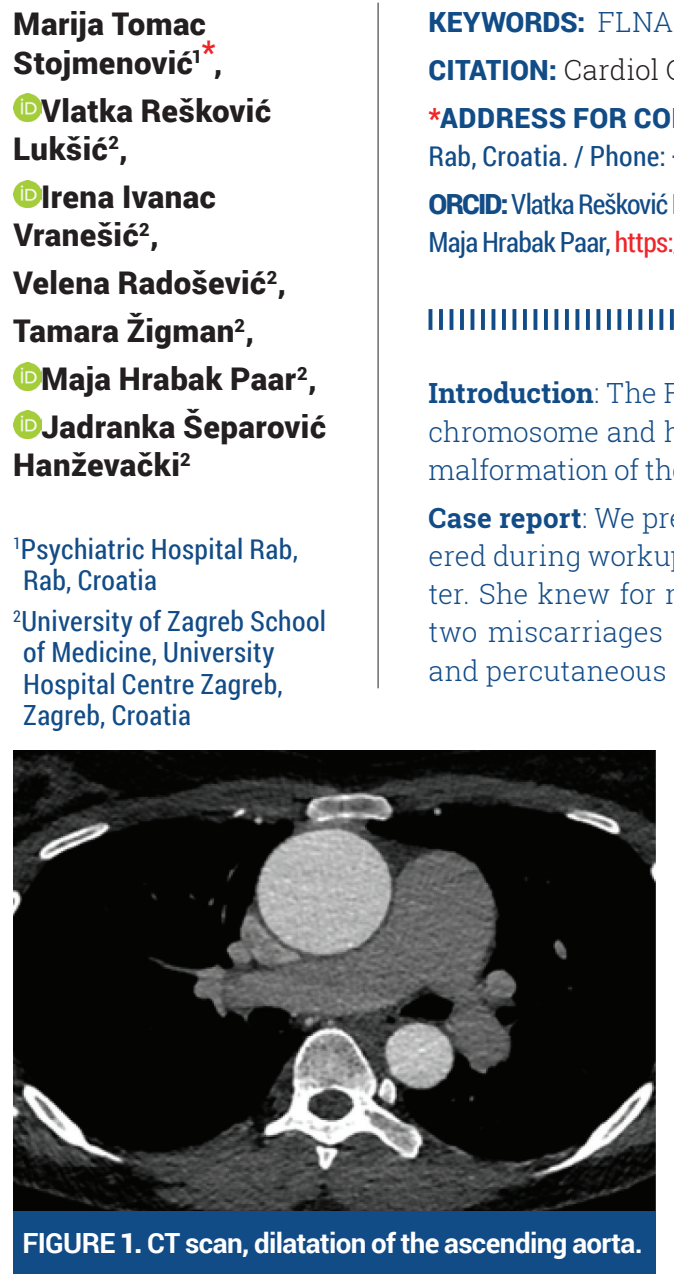

KEYWORDS: FLNA mutation, miscarriage, aortic dilatation, aortic dissection.

*ADDRESS FOR CORRESPONDENCE: Marija Tomac Stojmenović, Psihijatrijska bolnica Rab, Kampor 224, HR-51280 Rab, Croatia. / Phone: +385-95-910-2378 / E-mail: marija.tomac.mts@gmail.com

ORCID: Vlatka Rešković Lukšić, https://orcid.org/0000-0002-4721-3236 • Irena Ivanac Vranešić, https://orcid.org/0000-0002-6910-9720

Introduction: The FLNA gene provides instructions for producing protein filamin A. It is found on the X ( kup of older daughter's miscarriages. She had a double miscarriage in the first trimesmiscarriages and two successful deliveries, pulmonary hypertension, coronary artery disease conary intervention at the age of 56, grandmother from mother side had one successful delivery and three miscarriages, died at the age of 64 from diabetic coma Sister has moderate aortic regurgitation, dilatation of ascending aorta (42mm), one miscarriage. Father has dilatation of ascending aorta. In 2020. echocardiography revealed dilatation of the ascending aorta $(43 \mathrm{~mm})$ with mild central aortic regurgitation, and a trace of mitral regurgitation. The cardiologist recommended CT aortography and genetic testing. On CT aortography aorta was measured at a maximum of $46 \mathrm{~mm}$ (Figure 1). Genetic testing identified one pathogenic variant in FLNA. After this discovery, genetic testing was performed on all family members (Figure 2), and mutation was identified in the mother and sister. During this workup, the younger sister found out that she was pregnant. Soon, the mother suddenly died at the age of 60. Autopsy revealed a dissection of the thoracic aorta. With this finding, the younger sister went from category three to category four in classification of maternal cardiovascular risk score and was advised to abort. At the time of writing this paper she is 10 weeks pregnant and, knowing all the risks, does not want an abortion.

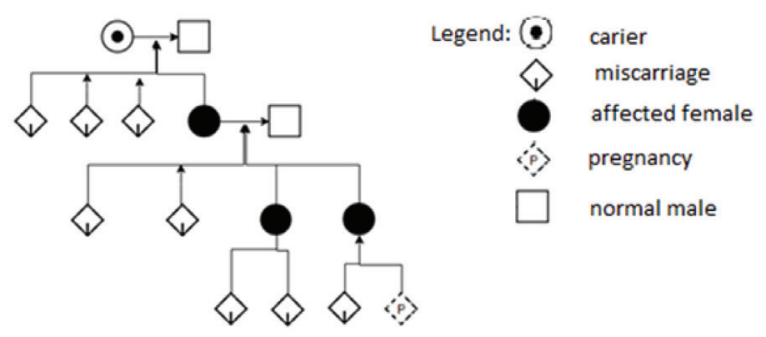

Conclusion: In young women with dilatation of ascending aorta, connective tissue disease should be considered. Today we have possibility for family screening, so we can discover pathogenic mutation in families. In FLNA mutation, safe size of ascending aorta dilatation is smaller than in healthy population, which should be considered during pregnancy planning. In case of pregnancy multidisciplinary approach is mandatory.

FIGURE 2. Genetic tree.

RECEIVED:

March 28, 2021

ACCEPTED:

April 2, 2021

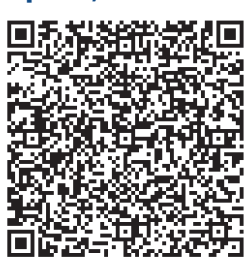

$\square$ Cardiologia Croatica 2021:16(5-6):188.

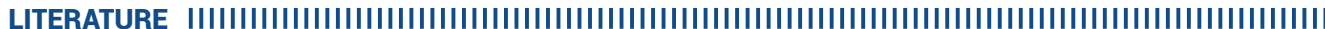

1. Chin JM, Bartholomew ML. Aortic aneurysm and dissection in pregnancy: A case report. Case Rep Womens Health. 2020 0ct 2;28:e00261. https:// doi.org/10.1016/j.crwh.2020.e00261

2. Reinstein E, Frentz S, Morgan T, García-Miñaúr S, Leventer RJ, McGillivray G, et al. Vascular and connective tissue anomalies associated with X-linked periventricular heterotopia due to mutations in Filamin A. Eur J Hum Genet. 2013 May;21(5):494-502. https://doi.org/10.1038/ ejhg.2012.209

3. Clarke CM, Fok VT, Gustafson JA, Smyth MD, Timms AE, Frazar CD, Smith JD, Birgfeld CB, Lee A, Ellenbogen RG, Gruss JS, Hopper RA, Cunningham ML. Single suture craniosynostosis: Identification of rare variants in genes associated with syndromic forms. Am J Med Genet A. 2018 Feb;176(2):290-300. https://doi.org/10.1002/ajmg.a.38540

4. de Wit MC, de Coo IF, Lequin MH, Halley DJ, Roos-Hesselink JW. Mancini GM. Combined cardiological and neurological abnormalities due to filamin A gene mutation. Clin Res Cardiol. 2011 Jan;100(1):45-50. https://doi.org/10.1007/s00392-010-0206-y 